\begin{tabular}{|c|c|}
\hline $\begin{array}{l}\mathrm{AD} \\
\text { iversitas } \\
\text { madDahlan }\end{array}$ & $\begin{array}{l}\text { Jurnal Psikologi Terapan dan Pendidikan } \\
\text { Vol. 2, No. 1, Mei 2020, pp. } 41-47 \\
\text { ISSN 275-2456 } \\
\text { http://journal.uad.ac.id/index.php/Psikologi/index }\end{array}$ \\
\hline
\end{tabular}

\title{
Hubungan antara adversity quotient dengan prestasi belajar siswa Madrasah Aliyah Negeri Kotawaringin Barat
}

\author{
Octavian Dwi Utaria,1, Ismira Dewi ${ }^{b, 2 *}$ \\ a,bFakultas Psikologi, Universitas Ahmad Dahlan, Yogyakarta \\ 10ctaviandwiiutarii@gmail.com; *2ismira.dewi@psy.uad.ac.id \\ *Correspondent Author
}

KATAKUNCI

adversity quotient; prestasi belajar; siswa
KEYWORDS

adversity quotient; learning achievement; student

\section{ABSTRAK}

Prestasi belajar merupakan salah satu indikator capaian dari proses yang dilakukan oleh setiap siswa. Oleh karena itu, pada setiap proses yang dilakukan membutuhkan daya juang atau adversity quotient yang tinggi agar siswa dapat belajar dengan optimal dan mencapai prestasi sesuai dengan yang diharapkan. Penelitian ini bertujuan untuk menguji secara empiris hubungan antara adversity quotient dengan prestasi belajar siswa Madrasah Aliyah Negeri Kotawaringin Barat. Metode yang digunakan pada penelitian ini adalah metode kuantitatif korelasi. Jumlah sampel yang digunakan pada penelitian ini sebanyak 67 siswa Madrasah Aliyah Negeri Kotawaringin Barat yang diperoleh dengan teknik cluster random sampling. Alat pengumpulan data untuk mengukur adversity quotient adalah skala adversity quotient yang disusun dengan merujuk pada teori Stoltz, sementara alat yang digunakan untuk mengukur prestasi belajar adalah menggunakan nilai rapor. Analisis data yang digunakan ialah teknik analisis korelasi product moment. Secara umum hasil yang diperoleh dari uji hipotesis menggunakan teknik analisis product moment menunjukan koefisien $r$ sebesar 0,748 dengan taraf signifikansi ( $\mathrm{p}$ ) sebesar $0,000(\mathrm{p}<0,01)$. Hasil penelitian menunjukan bahwa ada hubungan antara adversity quotient dengan prestasi belajar. Penelitian ini menyimpulkan bahwa semakin tinggi adversity quotient yang dimiliki siswa, maka semakin tinggi pula prestasi belajar pada siswa Madrasah Aliyah Negeri Kotawaringin Barat Kalimantan Tengah, dan sebaliknya.

The relationship between adversity quotient and student achievement at Madrasah Aliyah Negeri Kotawaringin Barat

Learning achievement is one indicator of the achievement of the process carried out by each student. Therefore, every process that is carried out requires a high fighting power or adversity quotient so that students can learn optimally and achieve achievements as expected. This study aims to test empirically the relationship between adversity quotient and student achievement at Madrasah Aliyah Negeri Kotawaringin Barat. The method in this research uses the quantitative method of correlation. The number of samples used in this study were 67 students of Madrasah Aliyah Negeri Kotawaringin Barat who were obtained by using cluster random sampling technique. The data collection tool to measure the adversity quotient is the adversity quotient scale, which is compiled with reference to the Stoltz theory, while the tool used to measure learning achievement is to use the report card scores. The data analysis used was the product moment correlation analysis technique. In general, the 
results obtained from hypothesis testing using product moment analysis techniques show the $r$ coefficient of 0.748 with a significance level $(p)$ of 0.000 ( $p$ <.01). The results showed that there was a relationship between adversity quotient and learning achievement. This study concludes that the higher the adversity quotient a student has, the higher the learning achievement of students at Madrasah Aliyah Negeri Kotawaringin Barat, Central Kalimantan, and in reverse.

This is an open-access article under the CC-BY-SA license.

\section{Pendahuluan}

Pada dasarnya manusia adalah seorang pembelajar sejati, yang akan terus belajar dimulai dari manusia dilahirkan kedunia hingga akhir hayat. Baik belajar secara formal maupun informal, di dalam dunia pendidikan, lingkungan, maupun keluarga. Secara formal lembaga pendidikan di Indonesia memiliki peran penting dalam mengambangkan potensi yang ada pada setiap peserta didik. Menurut Undang-undang RI Nomor 20 Tahun 2003 tentang Sistem Pendidikan Nasional Bab I Pasal 1 (1) pendidikan adalah "usaha sadar dan terencana untuk mewujudkan suasana belajar dan proses pembelajaran agar peserta didik secara aktif mengembangkan potensi dirinya, masyarakat, bangsa, dan negara".

Namun, dengan semakin kompleksnya dinamika kehidupan yang terjadi pada pendidik dan peserta didik dalam pembelajaran telah menjadi suatu tantangan dalam upaya mencapai tujuan pembelajaran. Menurut Oemar (2011) guru berperan penting sebagai pengajar, pembimbingan, dan berperan penting sebagai pendidik. Tidak hanya guru yang memiliki peran penting dalam menggapai prestasi belajar disekolah, dalam hal ini yang memegang peran penting dalam meningkatkan prestasi belajar adalah peserta didik itu sendiri yang selalu berusaha secara optimal untuk mencapai prestasi yang diinginkan. Menurut Chozaipah (2018) partisipasi besar yang dilakukan siswa akan menciptakan suasana keterbukaan antara guru dan siswa, sehingga kesulitan-kesulitan dalam belajar yang dialami siswa dapat diatasi secara cepat dan tepat.

Kecerdasan inteligensi atau yang sering disebut Intelligence Quotient (IQ) dinilai sebagai faktor utama yang mempengaruhi keberhasilan seseorang, termasuk mempengaruhi keberhasilan siswa dalan proses belajar. Slameto (2010) mengungkapkan bahwa intelegensi besar pengaruhnya terhadap kemajuan belajar. Dalam kehidupan nyata banyak contoh orang yang memiliki tingkat kecerdasan intelektual yang tinggi dan kecerdasan emosinal yang baik namun tidak dapat mengembangkan potensi yang telah dimiliki. Hal ini disebabkan dalam proses belajar siswa tidak hanya dihadapkan pada mata pelajaran saja, tetapi juga dihadapkan dengan beberapa tantangan baru dan hambatan yang mungkin saja dapat menyulitkan siswa dalam mengembangkan potensinya.

Stoltz (2000) menyatakan bahwa untuk mendapatkan prestasi belajar yang baik, dibutuhkan daya juang siswa agar dapat meraih hasil yang maksimal. Ketangguhan dan daya juang inilah yang dikonsepkan oleh Stoltz sebagai kecerdasan ketegaran atau daya juang yang disebut Adversity Quotient (AQ). Dijelaskan lebih lanjut bahwa seseorang dengna Adversity Quotient (AQ) dapat mengubah hambatan menjadi sebuah peluang bagi dirinya karena kecerdasan ini merupakan penentu seberapa jauh individu mampu bertahan dalam menghadapi dan mengatasi kesulitan (Stoltz, 2000).

Prestasi belajar diartikan sebagai tingkat keberhasilan siswa mencapai tujuan yang telah ditetapkan dalam sebuah program pengajaran. Prestasi belajar dapat ditunjukan melalui nilai yang diberikan oleh seorang guru dari jumlah bidang studi yang telah dipelajari oleh peserta didik. Indikator prestasi belajar adalah pengungkapan hasil belajar yang meliputi segenap 
ranah psikologis yang berakibat sebagai akibat pengalaman dan proses belajar siswa, yang terdiri dari ranah cipta, rasa, dan karsa. Untuk mendapatkan prestasi belajar yang baik memerlukan beberapa ranah atau aspek yaitu (1) ranah kognitif yang bertujuan untuk mengukur perkembangan penalaran siswa, (2) ranah afektif dengan sasaran pada perilaku siswa bukan pada pengetahuan siswa, dan (3) ranah psikomotorik dengan menggunakan pengukuran terhadap hasil-hasil belajar yang berupa keterampilan (Syah, 2010). Menurut Suryabrata (Hidayat, 2013) faktor lain yang mempengaruhi prestasi belajar adalah faktor internal yang meliputi aspek fisiologis (jasmaniah), aspek psikologis, dan faktor eksternal yang meliputi faktor sosisal dan non sosial. Ditambahkan pula oleh Ahmadi (2004) prestasi belajar yang dicapai seseorang merupakan hasil interaksi berbagai faktor yang mempengaruhinya baik dari dalam diri (faktor internal) maupun dari luar diri (faktor eksternal) individu. Prestasi tentu tidak akan terlepas dari pembahasan mengenai kecerdasan yang dimiliki seseorang. Namun berhasil atau tidaknya seseorang dalam meraih prestasinya tidak hanya bergantung pada kecerdasannya saja.

Hal ini didukung dengan penelitian Huda dan Mulyana (2018) bahwa terdapat pengaruh AQ terhadap prestasi akademik mahasiswa. Para mahasiswa memiliki kemampuan untuk bertahan saat menemui kesulitan yang ditemukan selama perkuliahan. Terlihat bahwa para mahasiswa dengan skor AQ tinggi dapat melampaui harapan-harapan atas kinerja dan potensinya. Keberhasilan siswa dalam proses belajar mengajar tergantung pada sikap siswa, untuk berdisiplin diri dan fokus menjalankan tugas dan kewajibannya. Siswa yang memiliki konsistensi diri yang baik dalam belajar akan dipastikan berimplikasi terhadap prestasi belajar siswa itu sendiri. Keberhasilan siswa dalam pembelajaran tergantung pada bagaimana cara siswa mengatasi kesulitan yang ada. Kecerdasan dipandang sebagai suatu hal yang sangat berperan dalam kesuksesan akademis siswa.

Adversity quotient merupakan kecerdasan individu dalam mengatasi setiap kesulitan yang muncul. Adversity quotient siswa dapat mendukung daya juang dalam menghadapi berbagai kesulitan yang mungkin saja muncul selama proses belajar mengajar yang dialami siswa itu sendiri. Permasalahan daya juang siswa tampaknya menjadi masalah utama (Supardi, 2013). Dijelaskan lebih lanjut oleh Parvathy dan Praseeda (2014) adversity quotient adalah kapasitas untuk menyesuaikan dengan kesulitan dalam kehidupan. Seseorang yang memiliki adversity quotient yang baik dapat mencapai tujuan dengan berjuang melawan segala rintangan serta menghadapi masalah. Siswa menghadapi banyak situasi atau tantangan dalam kehidupan sehari-hari mereka.

Beberapa teori yang mendasari munculnya adversity quotient adalah (1) psychoneuroimmunology yang merupakan konsep terintegrasi mengenai fungsi regulasi emosi-imun untuk mempertahankan homeostatis, (2) neurophysiologist yang mengatakan bahwa proses belajar berlangsung di wilayah sadar bagian luar yaitu cortex (3) psikologi kognitif yang merupakan salah satu kajian dalam psikologi yang memperlajari tentang persepsi, pemahaman alur pemikiran dan proses pemecahan masalah. Beberapa dimensi yang harus ada dalam adversity quotient adalah (1) control (kendali) merupakan kemampuan seseorang dalam mengendalikan dan mengelola sebuah peristiwa yang menimbulkan kesulitan di masa mendatang, (2) origin (asal-usul) dan ownership (pengakuan), origin yaitu dimana seseorang mempermasalahkan dirinya ketika mendapati bahwa kesalahan tersebut berasal dari dirinya, atau sejauh mana seseorang mempermasalahkan orang lain atau lingkungan yang menjadi sumber kesulitan atau kegagalan seseorang, (3) reach (jangkauan) yaitu sejauh mana kesulitan ini akan merambah kehidupan seseorang menunjukan bagaimana suatu masalah mengganggu aktivitas lainnya, sekalipun tidak berhubungan dengan masalah yang sedang dihadapi, (4) endurance (daya tahan) yang merupakan aspek ketahanan individu, sejauh mana kecepatan dan ketepatan seseorang dalam memecahkan masalah (Stoltz, 2000).

Berdasarkan pemaparan sebelumnya memperlihatkan bahwa adversity quotient dianggap sangat mendukung keberhasilan siswa dalam meningkatkan prestasi belajar. 
Dengan demikian penelitian ini bertujuan untuk menguji hubungan advesity quotient dengan prestasi belajar siswa Madrasah Aliah Negeri 1 Kotawaringin Barat. Harapannya adalah agar setiap siswa mengetahui adversity quotient yang dimiliki dan mampu menghadapi tantangan ataupun kesulitan dalam hidup, sehingga dapat mencapai prestasi sesuai dengan tujuannya.

\section{Metode}

Penelitian ini menggunakan metode kuantitatif dengan alat bantu skala adversity quotient (Stoltz, 2000). Skala ini untuk mengungkap aspek-aspek adversity quotient seperti control, origin dan ownership, reach, dan endurance dengan jumlah aitem sebanyak 42 aitem dan koefisien reliabilitas ( $\mathrm{rtt}$ ) sebesar 0,875 dan menggunakan hasil rata-rata nilai rapor untuk mengungkap prestasi belajar siswa sebagai variabel tergantung dari penelitian ini.

Pada penelitian ini terdapat satu variabel bebas dan satu variabel tergantung. Berdasarkan hipotesis dan tujuan penelitian untuk menguji ada atau tidaknya hubungan antara adversity quotient sebagai variabel bebas dan prestasi belajar sebagai variabel tergantung. Oleh karena itu analisis yang digunakan dalam penelitian ini menggunakan analisis korelasi product moment untuk menguji hipotesis penelitian. Data yang diperoleh dari penelitian dianalisis dengan menggunakan metode kompulasi statistic dan dengan bantuan program komputer SPSS 16.0 for windows.

\section{Hasil}

Hasil yang diperoleh dari unstandardized residual menunjukkan nilai KSZ sebesar 0,678 dengan nilai $p=0,747$. Dapat disimpulkan bahwa distribusi data memenuhi asumsi normalitas. Hasil yang diperoleh dari yang diuji dengan uji linearitas pada variabel adversity quotient dengan prestasi belajar menunjukkan bahwa $\mathrm{F}_{\text {linearity }}=128,62$ dan $\mathrm{F}_{\text {deviation from }}$ linearity $=1,847$. Diperoleh juga Sig. $p_{\text {linearity }}=0,000$ dan Sig. $p_{\text {deviation from linearity }}=0,053$ maka data kedua variabel yang dikorelasikan dapat dihubungakan dengan garis lurus atau linear.

Hasil kategorisasi variabel adversity quotient menunjukan bahwa dari 67 subjek penelitian 16,4\% subjek memiliki adversity quotient dalam kategori tinggi, 71,6\% subjek masuk dalam kategori sedang, dan 12,0\% dalam kategori rendah. Hal ini dapat disimpulkan bahwa mayoritas subjek penelitian yaitu siswa Madrasah Aliyah Negeri Kotawaringin Barat memiliki Kecerdasan adversity quotient yang cukup tinggi. Hasil dari kategori variabel prestasi belajar menunjukan bahwa dari 67 subjek penelitian, sebanyak 10,4\% subjek memiliki prestasi belajar yang tergolong tinggi, 35,8\% dalam kategori sedang, dan 53,7\% dalam kategori rendah. Hal ini menunjukan bahwa sebagaian besar subjek penelitian memiliki prestasi belajar dalam kategori rendah

Secara umum hasil yang diperoleh dari uji hipotesis dengan analisis menggunakan teknik analisis product moment diketahui bahwa nilai koefisien $r$ sebesar 0,748 dengan taraf signifikansi (p) sebesar 0,000 $(\mathrm{p}<0,01)$. Hal ini menujukan bahwa terdapat hubungan positif yang sangat signifikan antara variabel adversity quotient dengan prestasi belajar siswa-siswa MA Negeri Kotawaringin Barat. Adapun hasil analisis dapat dilihat pada tabel 1.

Tabel 1.

Hasil Uji Hipotesis

\begin{tabular}{lll}
\hline & $\boldsymbol{r}$ & $\boldsymbol{p}$ \\
\hline Variabel Adversity Quotient &, $748^{* *}$ &, 000 \\
\hline
\end{tabular}

\section{Pembahasan}

Secara umum hasil yang diperoleh dari uji Hipotesis pada tabel 1. memperlihatkan bahwa terdapat hubungan positif yang sangat signifikan antara variabel adversity quotient 
dengan prestasi belajar siswa-siswa Madrasah Aliyah Negeri Kotawaringin Barat. Hal ini mengartikan bahwa adversity quotient dapat menjadi salah satu prediktor untuk memprediksi prestasi belajar siswa.

Hasil analisis product moment menunjukan bahwa ada hubungan positif yang signifikan antara adversity quotient dengan prestasi belajar siswa Madrasah Aliah Negeri Kotawaringin Barat. Hasil penelitian ini didukung dengan penelitian sebelumnya yang dilakukan Saputo dkk (2013), yang menyatakan bahwa terdapat hubungan positif antara adversity quotient dengan prestasi belajar. Penelitian sejenis juga dilakukan oleh Yuninda (2011) menyatakan bahwa ada hubungan antara adversity quotient dengan prestasi akademik. Penelitian ini didukung oleh Zainudin (2011) bahwa ada peran adversity quotient dalam meningkatkan prestasi belajar siswa. Dijelaskan lebih lanjut bahwa adversity quotient sebagai kemampuan daya juang seseorang dalam menghadapi kesulitan atau persoalan untuk mencapai prestasi belajar yang optimal.

Adapun yang membedakan penelitian ini dengan penelitian sebelumnya yakni subjek yang digunakan pada penelitian ini berada di sekolah Madrasah Aliah Negeri Kotawaringin Barat. Prestasi belajar sebagian besar bergantung pada AQ sebagai kecerdasan/kemampuan daya juang dalam menghadapi kesulitan atau persoalan untuk mencapai prestasi belajar yang optimal. Hal ini menunjukkan bahwa orang dengan adversity quotient tinggi mengungguli mereka yang AQ-nya rendah (Stoltz, 2002).

Hasil kategorisasi variabel adversity quotient bahwa dari 67 subjek penelitian 16,4\% subjek memiliki adversity quotient dalam kategori tinggi, 71,6\% subjek masuk dalam kategori sedang, dan 12,0\% dalam kategori rendah. Hal ini dapat disimpulkan bahwa mayoritas subjek penelitian yaitu siswa Madrasah Aliyah Negeri Kotawaringin Barat memiliki Kecerdasan adversity quotient yang sedang.

Hasil dari kategori variabel prestasi belajar bahwa dari 67 subjek penelitian, sebanyak 10,4\% subjek memiliki prestasi belajar yang tergolong tinggi, 35,8\% dalam kategori sedang, dan $53,7 \%$ dalam kategori rendah. Hal ini menunjukan bahwa sebagaian besar subjek penelitian memiliki prestasi belajar dalam kategori rendah. Menurut Immaculata dan Yuli (2013) bahwa ada beberapa faktor yang mempengaruhi prestasi belajar yaitu faktor motivasi, faktor lingkungan sosial yang terdiri dari relasi antara anggota keluarga dan relasi antar siswa dengan siswa lainnya, faktor psikologis yang terdiri dari Emotional Quotient (EQ), kebiasaan belajar, perhatian, modernitas individu, sikap dan kesiapan serta faktor Intelligence Quotient (IQ).

Ditambahkan pula oleh Syah (2010) bahwa faktor-faktor yang mempengaruhi belajar siswa dapat dibedakan menjadi tiga macam yakni; pertama, faktor internal. Faktor internal dalam diri siswa yakni kondisi jasmani/ fisiologis, kondisi umum jasmani dan tonus (tegangan otot) yang menandai tingkat kebugaran organ-organ tubuh dan sendi-sendinya, dapat memengaruhi semangat dan intensitas siswa dalam mengikuti pelajaran. Kondisi organ-organ khusus siswa, seperti tingkat kesehatan indera pendengar dan indera penglihatan, juga sangat memengaruhi kemampuan siswa dalam menyerap informasi dan pengetahuan yang diberikan di kelas.

Kedua, faktor eksternal, yang terdiri atas dua macam, yakni faktor lingkungan sosial dan faktor lingkungan nonsosial. Lingkungan sosial yang paling banyak mempengaruhi belajar adalah orangtua dan keluarga siswa itu sendiri. Lingkungan sosial sekolah seperti para guru, para tenaga kependidikan, dan teman sekelas dapat memengaruhi semangat belajar seorang siswa. Faktor-faktor yang termasuk lingkungan nonsosial ialah gedung sekolah dan letaknya, rumah tempat tinggal keluarga siswa dan letaknya, alat-alat belajar, keadaan cuaca, dan waktu belajar yang digunakan siswa. Ketiga, faktor pendekatan belajar. Pendekatan belajar dapat dipahami sebagai keefektifan segala cara atau strategi yang digunakan siswa dalam menunjang efektivitas dan efisiensi proses belajar materi tertentu.

Hasil penelitian ini menunjukkan bahwa adversity quotient siswa Madrasah Aliyah Negeri Kotawaringin Barat masuk dalam kategori sedang. Sebagaimana dijelaskan bahwa 
terdapat dimensi adversity quotient yang berpengaruh pada prestasi akademik siswa. Pertama, control (kendali). Kendali diri ini akan berdampak pada tindakan selanjutnya atau respon yang dilakukan oleh siswa, untuk tetap berusaha keras mencapai prestasi yang diinginkannya walau sesulit apapun keadaannya. Kedua, origin-ownership (asal usul dan pengakuan). Origin yaitu asal usul dari kesulitan yang dialami; siapa atau apa yang menyebabkan kesulitan itu bisa terjadi, berkaitan dengan rasa bersalah. Rasa bersalah melihat sejauh mana siswa mempermasalahkan dirinya, orang lain (guru, temannya, dan lainlain), atau lingkungannya saat menjadi sumber kesulitan atau kegagalan yang dialami. Rasa bersalah yang tepat akan menggugah seseorang untuk bertindak, serta untuk bertanggung jawab atas kesalahan atau kegagalan tersebut.

Ketiga, reach (jangkauan). Sejauh mana kesulitan ini akan berdampak pada hal lain dalam kehidupan, sekalipun tidak berhubungan dengan masalah yang sedang dihadapi. Adversity quotient yang rendah pada siswa akan membuat kesulitan meluas pada hal lain dalam kehidupannya. Semakin rendah skor reach pada seseorang, semakin besar pula kemungkinan dia menganggap bahwa peristiwa buruk yang terjadi adalah suatu bencana, dan setelah itu membiarkannya meluas pada situasi yang lain. Keempat, endurance (daya tahan). Endurance mempertanyakan berapa lama kesulitan ini akan berlangsung dan berapa lama penyebab kesulitan ini akan berlangsung. Endurance melihat ketahanan individu, yaitu sejauh mana seseorang dapat memecahkan masalah. Dengan demikian aspek ini melihat berapa lama kesulitan dan penyebab kesulitan tersebut akan berlangsung.

Dijelaskan pula oleh Stoltz (2000) bahwa kesuksesan seseorang dalam pekerjaan dan sebagian besar kehidupan ditentukan oleh adversity quotient termasuk di dalamnya prestasi belajar. Individu yang merespon terhadap kesulitan sebagai sesuatu yang bersifat tetap, internal dan dapat mempengaruhi secara umum terhadap bagian lain dari kehidupan individu, memiliki kecenderungan untuk selalu merasa gagal. Namun bagi individu yang dapat menerima suatu kesulitan sebagai sesuatu yang sifatnya ekternal,sementara dan terbatas, cenderung menikmati banyak manfaat berkisar kinerja hingga pencapaian keberhasil atau prestasi.

Setiap orang harus memiliki kemampuan untuk menghadapi tantangan dan kesulitan dalam hidupnya. Oleh karena itu, untuk meningkatkan adversity quotient seseorang harus memiliki empati, simpati dan kemampuan untuk memahami masalah orang lain. Ia harus memahami penyebab dasar masalah dan menemukan cara untuk mengatasi masalah tersebut (Parvathy \& Praseeda, 2014).

Adapun keterbatasan dalam penelitian ini, penulis tidak mengukur variabel lain yang dapat mempengaruhi prestasi belajar pada siswa, salah satunya adalah IQ (Intelligence Qoutient). IQ merupakan faktor internal yang dapat mempengaruhi prestasi belajar. Kecerdasan dapat menentukan pencapaian keberhasilan dalam belajar. Oleh sebab itu, untuk peneliti selanjutnya dihadapkan mampu mengukur variabel lain yang mempengaruhi prestasi belajar pada siswa.

\section{Simpulan}

Berdasarkan hasil analisis data dalam penelitian pada siswa Madrasah Aliyah Negeri Kotawaringin Barat, maka kesimpulan yang dapat diambil bahwa terdapat hubungan positif yang sangat signifikan antara adversity quotient dengan prestasi belajar siswa Madrasah Aliyah Negeri Kotawaringin Barat. Hal ini mengartikan bahwa semakin tinggi adversity quotient maka semakin tinggi pula prestasi belajar pada siswa Madrasah Aliyah Negeri Kotawaringin Barat Kalimantan Tengah. Variabel adversity quotient memberikan sumbangan efektif sebesar 55,9\% terhadap prestasi belajar. Hasil penelitian ini menunjukan bahwa prestasi belajar siswa Madrasah Aliyah Negeri Kotawaringin Barat tergolong rendah, yaitu sebesar 53,7\%, sedangkan adversity quotient siswa berada dalam kategori sedang sebesar $71,6 \%$. 


\section{DAFTAR PUSTAKA}

Chozaipah. (2018). Peran dan partisipasi siswa dalam pembelajaran terhadap prestasi belajar Akuntansi di SMKN 1 Dumai Provinsi Riau. Jurnal Serambi PTK. 5(1). 60-65

Hastuti, T. D, Sari. D. R, \& Riyadi. (2017). Student profile with high adversity quotient in Math learning. Journal of Psysics: Conf. Series 983, 012131.

Hema, S. \& Gupta, S. M. (2015). Adversity quotient for prospective higher education. The International Journal of Indian Psychology. 2(3). 49-64.

Hidayat, S. \& Ansori. (2013). Manajemen pendidikan substansi dan implementasi dalam praktik pendidikan di Indonesia. Tanggerang: Pustaka Mandiri.

Huda, T.N \& Mulyana, A. (2008). Pengaruh adversity quotient terhadap prestasi belajar. Psympathic. Jurnal Ilmiah Psikologi. 4(1). 115-132.

Parvathy, U \& Praseeda, M. (2014). Relationship between adversity quotient and academic problems among student teachers. IOSR Journal of Humanities and Social Science. 19(11). 23-26.

Sapuri, R. (2009). Psikologi Islam: Tuntunan jiwa manusia modern. Jakarta: Rajawali Press

Slameto. (2010). Belajar dan faktor-faktor yang mempengaruhinya. Cetakan keenam. Jakarta: Rineka Cipta.

Stoltz, P.G. (2000). Adversity quotient: Mengubah hambatan menjadi peluang. Jakarta: PT Grasindo.

Stoltz, P. G. (2002). Adversity quotient@work: Make everyday challenges the key to your success-putting the principles of $A Q$ into action. New York: Morrow.

Supardi, US. (2013). Pengaruh adversity qoutient terhadap prestasi belajar matematika. Jurnal Formatif 3(1): 61-71

Syah, M. (2010). Psikologi pendidikan dengan pendekatan baru (Edisi Revisi). Bandung: PT. Remaja Rosdakarya

Oemar, H. (2011). Kurikulum dan pembelajaran. Jakarta: Bumi Aksara.

Undang-Undang RI No. 20. (2003). Sistem pendidikan nasional. Jakarta: Depdiknas.

Yuninda, H. (2011). Hubungan antara motivasi berprestasi dan adversity quotient dengan prestasi akademik siswa SMAN 1 Malang. Skripsi. Fakultas Ilmu Pendidikan UM.

Zainuddin. (2011). Pentingnya adversity quotient dalam meraih prestasi belajar. Pontianak: Universitas Tanjungpura. 